\title{
Soil Carbon, Glomalin, And Aggregation in Onion Crop Under No-Tillage with Cover Crops or Conventional Tillage Systems for Eight Years
}

Juliana Gress Bortolini (Corresponding Author)

Center of Agricultural Sciences, Program of Plant Genetic Resources, Federal University of Santa Catarina (UFSC), 88034-000, Florianópolis, SC, Brazil.

Tel: (48) $37215404 \quad$ E-mail: julianagbortolini@gmail.com

\section{Cláudio Roberto Fonsêca Sousa Soares}

Center of Biological Sciences, Department of Microbiology, Immunology, and Parasitology, Federal University of Santa Catarina (UFSC), 88040-900, Florianópolis, SC, Brazil.

Tel: (48) $37215404 \quad$ E-mail: crfsoares@gmail.com

Matheus Junckes Muller

Center of Agricultural Sciences, Agronomy Course, Federal University of Santa Catarina (UFSC), SC, Brazil.

Tel: (48) $37215404 \quad$ E-mail: matheusjunckes@yahoo.com.br

Guilherme Wilbert Ferreira

Center of Agricultural Sciences, Program of Agroecosystems, Federal University of Santa Catarina (UFSC), SC, Brazil.

Tel: (48) $37215404 \quad$ E-mail: guilhermewferreira@hotmail.com

\section{Edenilson Meyer}

Center of Agricultural Sciences, Program of Plant Genetic Resources, Federal University of Santa Catarina (UFSC), 88034-000, Florianópolis, SC, Brazil.

Tel: (48) $37215404 \quad$ E-mail: edenilsonmeyer@hotmail.com 
Caroline Krug Vieira

Environmental Engineering Program, Regional University of Blumenau (FURB), SC, Brazil, 89030-903, Blumenau, SC, Brazil.

Tel: (48) $37215404 \quad$ E-mail: carolkvieira@gmail.com

Monique Souza

Center of Agricultural Sciences, Department of Rural Engineering, Federal University of Santa Catarina (UFSC), SC, Brazil.

Tel: (48) $37215404 \quad$ E-mail: monique_souzaaa@yahoo.com.br

\section{Claudinei Kurtz}

Company of Agricultural Research and Rural Extension of Santa Catarina (EPAGRI), Ituporanga, SC, Brazil.

Tel: (48) $37215404 \quad$ E-mail: kurtz@epagri.sc.gov.br

\section{Cledimar Rogério Lourenzi}

Center of Agricultural Sciences, Department of Rural Engineering, Federal University of Santa Catarina (UFSC), SC, Brazil.

Tel: (48) $37215404 \quad$ E-mail: lourenzi.c.r@ufsc.br

\section{Paulo Emílio Lovato}

Center of Agricultural Sciences, Department of Rural Engineering, Federal University of Santa Catarina (UFSC), SC, Brazil.

Tel: (48) $37215404 \quad$ E-mail: paulo.lovato@ufsc.br

\section{Arcangelo Loss}

Center of Agricultural Sciences, Department of Rural Engineering, Federal University of Santa Catarina (UFSC), SC, Brazil.

Tel: (48) $37215404 \quad$ E-mail: arcangeloloss@yahoo.com.br

Jucinei José Comin 
Center of Agricultural Sciences, Department of Rural Engineering, Federal University of Santa Catarina (UFSC), SC, Brazil.

Tel: (48) 37215404

E-mail: j.comin@ufsc.br

Received: January 13, 2021

Accepted: February 22, 2021

Published: March 8, 2021

doi:10.5296/jas.v9i2.18196

URL: https://doi.org/10.5296/jas.v9i2.18196

\begin{abstract}
Crop systems using cover crops affect soil physical, chemical, and biological attributes, including aggregate formation. This work aims to evaluate winter cover crop species' effect on soil total organic carbon, glomalin, and aggregation in areas with onion crops in a no-tillage vegetable production system (NTVS) and conventional tillage system (CTS) for eight years. The experiment treatments were: control, with natural vegetation(NV); black oats (Avena strigosa); rye(Secale cereale);oilseed radish(Raphanus sativus);intercropped black oats and oilseed radish; intercropped rye and oilseed radish; and a conventional tillage systems area. A 33-year old adjacent secondary forest was evaluated as a reference for undisturbed conditions. We assessed soil total organic carbon, total glomalin, and easily extractable glomalin in three soil layers (0-5, 5-10, and 10-20 cm depth). Undisturbed samples were used to quantify soil aggregate stability, aggregation indexes (weighted mean diameter; geometric mean diameter), aggregate mass distribution (macroaggregates, mesoaggregates), and macroaggregate carbon contents. The conventional tillage areas had the lowest weighted mean soil aggregate diameter, geometric mean diameter, and macroaggregate mass. Those areas also had the lowest bulk soil and aggregate organic carbon contents and the lowest total and easily extractable glomalin. Winter cover crops' use resulted in a $10 \%$ higher aggregate weighted mean diameter and geometric mean diameter. Areas with cover crops had 13\% higher organic carbon contents in aggregates and 17\% higher macroaggregate mass than conventional tillage areas. The highest values of total and easily extracted glomalin occurred in plots with black oats. Winter cover crops, single or intercropped, improved physical attributes of soils with onion crops under not-tillage compared to conventional tillage areas.
\end{abstract}

Keywords: soil physical attributes, geometric mean diameter, bulk soil, aggregate stability, chemical and biological attributes

\title{
1. Introduction
}

Onion (Allium cepa L) is an economically important vegetable in Brazil, especially its southernmost states (Hammerschimidt et al., 2013). The Upper Itajai River Valley, in Santa Catarina, has the highest number of producers, who grow approximately 20,000 hectares of onion, more than $30 \%$ of the Brazilian production (EPAGRI/CEPA, 2019). Most of the crop is grown under a conventional tillage system (CTS), with intensive soil mobilization, 
chemically-synthesized fertilizers, and pesticides, leading to environmental impacts, such as erosion and nutrient leaching (Panachucki et al., 2011; Altieri et al., 2011).

Farmers in the Upper Itajai River Valley have been adopting the no-tillage vegetable production system (NTVS) to minimize the CTS impacts. The NTVS restricts soil mobilization to the planting rows, has a permanent cover with plants or their residues, and balanced fertilization. Plants diversity is maintained through rotation (legume, grass, cruciferous, and others) and the use of single or intercropped cover plants, aiming to improve family farmers' autonomy and promote sustainable rural development (Mafra et al., 2019).

Cover crop species improve soil physical and chemical attributes in onion fields (Loss et al., 2017; Comin et al., 2018a; Santos et al., 2018; Ferreira et al., 2018) as well as soil biological properties (Silva et al., 2014). They also lead to lower weed emergence, affecting onion yield and quality (Vilanova et al., 2014; Oliveira et al., 2016; Comin et al., 2018b; Souza et al., 2018). However, successive onion crops can affect soil characteristics, which requires evaluating the long-term effects of soil management systems.

Plant growth and decomposition of their residues on soils affect soil water infiltration, prevents erosive processes, lowers thermal amplitude, and increases nutrient cycling, organic matter (SOM), cation exchange capacity (CEC), and the sum of bases (Loss et al., 2017; Santos et al., 2018, Upton et al., 2019). Weed competition also tends to be lower because of plant residues' physical barrier (Comin et al., 2018a; Souza et al., 2018).

The residues of cover crops on the soil surface can prevent weed germination and emergence by releasing allelopathic compounds or creating a physical barrier (Altieri et al., 2011). Cover crops can reduce costs with weed management and prevent germination of dormant weeds from the soil seed bank (Brennan \& Smith, 2005). Souza et al. (2018) evaluated different cover crops under NTVS and found a higher weed suppression with rye, barley, or black oats, especially at the beginning of the onion cycle, when there is more competition by weeds. In another work carried out in the same area of our study, the treatments with oilseed radish, rye, or oilseed radish + rye had the highest cover crops yield, which resulted in lower weed dry matter at the beginning of the onion crop cycle (Vilanova et al. 2014).

Cover crops affect both SOM accumulation and soil aggregation, responsible for soil structure and SOM protection. Some studies relate those gains with cover crops' ability to form a dense, fasciculate root system, with rapid establishment and exploration of the soil profile at greater depths (Loss et al., 2017; Ferreira et al., 2018).

Cover crop roots can associate with Arbuscular Mycorrhizal Fungi (AMF), which are responsible for another factor connected to soil aggregation: the production of glycoproteins (glomalin) (Rillig et al., 2003). Glomalin is produced by AMF hyphae, acting as a cementing agent (Wright et al., 1996) that assists in the formation and stabilization of soil aggregates and the dynamics of carbon (C) and nitrogen (N) stocks in the soil (Nichols \& Wright, 2005).

Wright et al. (1996) evaluated the correlation between glomalin fractions and aggregate stability in crop areas and found negative impacts of soil tillage, with decreases in the glomalin fractions and consequent decreases in soil $\mathrm{C}$ contents and aggregation indexes. A 
positive correlation between total glomalin and soil $\mathrm{C}$ has also been found, confirming this glycoprotein's contribution to aggregate stability (Wright \& Upadhyaya, 1998).

This work aimed to evaluate the effect of different winter cover species on total organic carbon (TOC), glomalin, and aggregation in soils with onion crops under NVTS and CTS for eight years.

\section{Method}

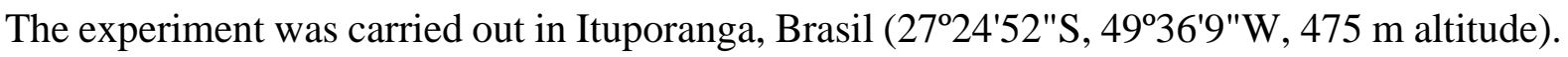
The region has a humid mesothermal subtropical climate $(\mathrm{Cfa})$, according to the Köppen classification, with a mean annual temperature of $17.6 \mathrm{C}$ and a mean annual rainfall of 1,400 mm (Souza et al., 2013).

The soil is a Humic Inceptisol (Cambissolo Húmico, EMBRAPA, 2013). Mean air temperature, rainfall, and irrigation doses during the study period are shown in Figure 1. The climate data were obtained from the meteorological station located approximately 300 meters from the experimental area.

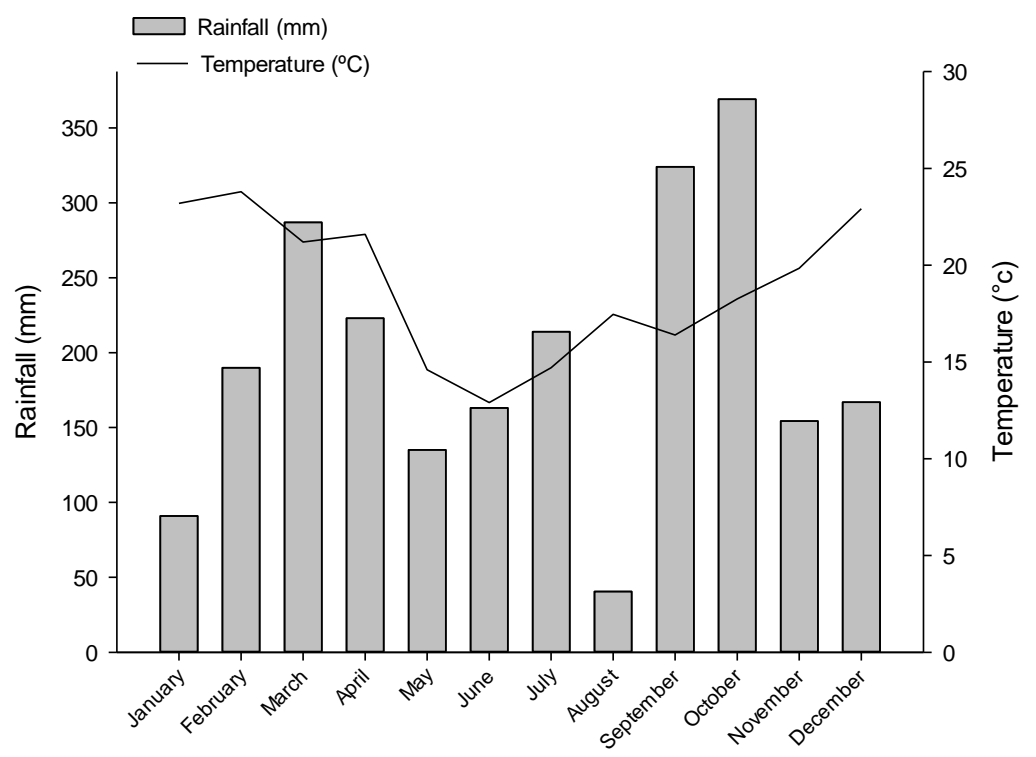

Figure 1. Mean air temperature and rainfall in the experiment area.

The area has a history of 20 years with crops in conventional tillage system (CTS), with plowing and harrowing until 1996, when a minimum tillage system was implemented, with onion crops in rotation with cover crops - black oats (Avena strigosa), velvet bean (Mucuna aterima), millet (Pennisetum glaucum), sun hemp (Crotalaria juncea), and vetch (Vicia sativa). This system was used from 1996 to 2007 when sweet potato was planted and grown in the area for two years. In 2009, the experiment with onion in NTVS was implemented. The natural vegetation in the area was desiccated in April 2009, and lime was applied to increase soil pH to 6.0 . 
The treatments in NTVS were: control, using natural vegetation (NV); Avena strigosa (black oats; BO), using $120 \mathrm{~kg}$ seeds $\mathrm{ha}^{-1}$; Secale cereale (rye; RY), using $120 \mathrm{~kg}$ seeds $\mathrm{ha}^{-1}$; Raphanus sativus (oilseed radish - OR), using $120 \mathrm{~kg}$ seeds ha $\mathrm{h}^{-1}$; black oats (60 kg seeds $\left.\mathrm{ha}^{-1}\right)+$ oilseed radish $\left(10 \mathrm{~kg}\right.$ seeds $\left.\mathrm{ha}^{-1}\right)(\mathrm{BO}+\mathrm{OR})$; and rye $\left(60 \mathrm{~kg}\right.$ seeds $\left.\mathrm{ha}^{-1}\right)+$ oilseed radish $\left(10 \mathrm{~kg}\right.$ seeds ha $\left.{ }^{-1}\right)(\mathrm{RY}+\mathrm{OR})$. An area with CTS was kept for comparison with the NTVS, with onion crops grown in rotation with $P$. glaucum (millet) in the summer. The CTS consisted of plowing, harrowing, and scarification. The CTS area had been used for approximately 40 years when the samples were collected. A secondary forest in regeneration for approximately 33 was evaluated as a reference for the soil under natural conditions.

The cover crops species were broadcast sowed, and a no-tillage seed drill was passed twice on the soil surface to incorporate the seeds lightly into the soil. Soil fertilization, irrigation, and cultural practices were not used in the experimental area during winter cover crops. The amounts of cover crop seeds were based on the highest rates indicated by Monegat (1991) + $50 \%$. The treatments were arranged in a randomized block design with four replications, and each experimental unit had $25 \mathrm{~m}^{2}(5 \times 5 \mathrm{~m})$.

Three cover crop biomass subsamples from each plot were collected using a $0.5 \times 0.5 \mathrm{~m}\left(0.25 \mathrm{~m}^{2}\right)$ frame, 60, 80, and 120 days after cover crop sowing (DAS). The plant samples were dried in a forced-air circulation oven at $65{ }^{\circ} \mathrm{C}$ until constant mass and weighed to estimate its dry matter (DM) yield (Table 1). Subsequently, the biomass samples were returned to the study area.

Table 1. Winter soil cover crop dry matter (DM) and onion yield

\begin{tabular}{|c|c|c|c|c|c|}
\hline \multirow[t]{3}{*}{ Land use system } & \multicolumn{4}{|c|}{ Plant dry matter $\left(\mathrm{Mg} \mathrm{ha}^{-1}\right)^{1}$} & \multirow{3}{*}{$\begin{array}{c}\text { Onion yield } \\
\text { Mg ha'-1 }\end{array}$} \\
\hline & \multicolumn{3}{|c|}{ Winter $^{2}$} & \multirow{2}{*}{$\begin{array}{c}\text { Summer }^{3} \\
120\end{array}$} & \\
\hline & 60 & 80 & 120 & & \\
\hline NV & 0.45 & 0.65 & 1.41 & 1.97 & 16.4 \\
\hline $\mathrm{BO}$ & 1.75 & 2.40 & 3.79 & 8.45 & 21.5 \\
\hline RY & 1.82 & 2.22 & 4.13 & 9.03 & 21.7 \\
\hline OR & 1.23 & 1.46 & 3.77 & 9.25 & 19.3 \\
\hline $\mathrm{BO}+\mathrm{OR}$ & 1.83 & 2.17 & 4.62 & 9.85 & 24.4 \\
\hline $\mathrm{RY}+\mathrm{OR}$ & 1.90 & 2.19 & 3.92 & 8.48 & 21.4 \\
\hline $\mathrm{CTS}^{4}$ & - & - & - & 8.00 & 19.8 \\
\hline
\end{tabular}

$\mathrm{NV}=$ natural vegetation; $\mathrm{BO}=$ black oats; $\mathrm{RY}=$ rye $\mathrm{OR}=$ oilseed radish; $\mathrm{CTS}=$ 
conventional tillage system. ${ }^{(1)} \mathrm{DM}$ of winter and summer soil cover crops. ${ }^{(2)} \mathrm{DM}$ of winter soil cover crops at 60,80 , and 120 days after sowing. ${ }^{(3)} \mathrm{DM}$ of summer velvet bean (Mucuna aterrima) at 120 dias. ${ }^{(4)} \mathrm{DM}$ of summer millet (Pennisetum glaucum) at 120 days.

Those procedures were repeated for eight years when disturbed, and undisturbed soil samples were collected to determine aggregate stability, total organic carbon (TOC), and glomalin. A $40 \times 40 \times 40 \mathrm{~cm}$ trench was opened in each plot to collect soil samples in the $0-5,5-10$, and 10-20 $\mathrm{cm}$ layers, using a spade and a spatula.

Undisturbed samples were manually disaggregated following cracks or weak points and sieved (8.00-mm and 4.00-mm mesh) to obtain the soil aggregates, according to Embrapa (1997). Disturbed samples were air-dried and sieved (2.00-mm mesh) to quantify total organic carbon contents. Twenty-five grams of the aggregates retained in the $4.00-\mathrm{mm}$ mesh sieve were placed in a set of sieves with decreasing mesh diameters of 2.00, 1.00, 0.50, 0.25, and $0.105 \mathrm{~mm}$. The aggregates placed on the $2.00 \mathrm{~mm}$ mesh sieve were moistened with a manual sprayer and subjected to vertical wet sieving for 15 minutes in a Yoder device (Yoder, 1936). The material retained in each sieve was placed in Petri dishes and dried at $105^{\circ} \mathrm{C}$ until constant weight. The mass of soil aggregates was used to calculate the soil aggregation indexes (geometric mean diameter - GMD; and weighted mean diameter - WMD), according to Embrapa (1997). The aggregate mass distribution was evaluated considering the mean diameter classes, according to Costa Jr. et al. (2012): $8.00>\varnothing \geq 2.0 \mathrm{~mm}$ (macroaggregates); $2.0>\varnothing \geq 0.25 \mathrm{~mm}$ (mesoaggregates); and $\varnothing<25 \mathrm{~mm}$ (microaggregates). Part of the aggregates passed through the $8.00 \mathrm{~mm}$ mesh sieve and was retained in the $4.00 \mathrm{~mm}$ mesh sieve was macerated and sieved in a $2.00 \mathrm{~mm}$ mesh sieve for TOC quantification. The TOC contents were determined in aggregates $(8.00>\varnothing \geq 2.0 \mathrm{~mm})$ and bulk soil $(\varnothing<2.0 \mathrm{~mm})$, according to Yeomans \& Bremner (1988).

Disturbed soil samples from the $0-10 \mathrm{~cm}$ layer, collected with an auger, were used to estimate total glomalin (TG) and easily extractable glomalin (EEG) contents, as described by Bradford (1976) and modified by Wright \& Upadhyaya (1998). Each $1.0 \mathrm{~g}$ soil sample was placed in a $15-\mathrm{mL}$ Falcon tube with $8.0 \mathrm{~mL}$ of sodium citrate $(50 \mu \mathrm{mol})$, and the solution was autoclaved at $121{ }^{\circ} \mathrm{C}$ for one hour. The supernatant was collected and measured, and the procedure was repeated until the supernatant showed a light-yellow color. The EEG content was determined after a single 1-hour autoclaving cycle.

The data were evaluated for normality and homogeneity using the Lilliefors and Cochran tests and subjected to ANOVA. When there were significant effects, means were separated using the Skott-Knott test at $5 \%$ probability. The TOC contents in the soil aggregates $(8.00>\emptyset \geq 2.0 \mathrm{~mm})$ and bulk soil $(\varnothing<2.0 \mathrm{~mm})$ were analyzed separately in each treatment, and when there were significant differences, they were compared with the Fischer's LSD test at 5\% probability. Subsequently, the Pearson correlation analysis $(\mathrm{p} \leq 0.05)$ was used for the attributes related to soil aggregation and TOC and glomalin contents. Reference area (native forest) data were expressed as a mean \pm confidence interval (mean \pm CI 95\%). Statistical analyses were carried out using the Sisvar 5.6 program. A principal component analysis (PCA) was carried out using 
the prcomp command of the ggfortify package, and the correlation of the variables with the PCA axis was carried out using the package factoextra in the R 3.6 program.

\section{Results}

\subsection{Total Organic Carbon in Soil Aggregates and Bulk Soil}

TOC contents in soil aggregates $(8.00>\emptyset \geq 2.0 \mathrm{~mm})$ from the top layer $(0-5 \mathrm{~cm})$ were similar in all treatments, with or without winter cover crops. However, in bulk soil $(\varnothing<2.0 \mathrm{~mm})$, the lowest TOC contents occurred in the CTS treatment, while the highest TOC appeared in the plots with OR and BO+OR. The use of black oats (BO), rye (RY), and oilseed radish (OR), single or intercropped, resulted in a $25 \%$ increase in TOC in comparison with areas with CTS (Table 2). In the 0-5 cm layer, TOC in aggregates was $17 \%$ higher in RY than in bulk soil (Table 2). In the CTS area, TOC contents $13 \%$ higher in aggregates than in bulk soil.

In the 5-10 cm soil layer, the OR treatment had the highest aggregate TOC content (Table 2). The bulk soil in the intercropped RY+OR had a $16 \%$ increase in TOC compared to all other treatments. The bulk soil samples in the treatments with cover crops hand, on average, $20 \%$ higher TOC than the CTS area. TOC in the OR plots was $15 \%$ higher than in bulk soil. In the 5-10 cm soil layer, the OR treatment had the highest aggregate TOC content (Table 2). The bulk soil in the intercropped RY+OR had a 16\% increase in TOC than all other treatments. The bulk soil samples in the treatments with cover crops hand, on average, 20\% higher TOC than the CTS area. TOC in the OR plots was $15 \%$ higher than in bulk soil.

Table 2. Total organic carbon $\left(\mathrm{kg} \mathrm{ha}^{-1}\right)$ in aggregates and bulk soil in the 0-5, 5-10, and 10-20 $\mathrm{cm}$ layers of soils under different management systems for onion crop

\begin{tabular}{|c|c|c|c|c|c|c|c|c|c|}
\hline \multirow{3}{*}{ Treatments } & \multicolumn{9}{|c|}{ Total organic carbon $\left(\mathbf{k g ~ h a}^{-\mathbf{1}}\right)$} \\
\hline & \multicolumn{2}{|c|}{$0-5 \mathrm{~cm}$} & \multirow{2}{*}{$\begin{array}{l}\mathrm{CV} \\
(\%)\end{array}$} & \multicolumn{2}{|c|}{$5-10 \mathrm{~cm}$} & \multirow{2}{*}{$\begin{array}{l}\mathrm{CV} \\
(\%)\end{array}$} & \multicolumn{2}{|c|}{$10-20 \mathrm{~cm}$} & \multirow{2}{*}{$\begin{array}{l}\mathrm{CV} \\
(\%)\end{array}$} \\
\hline & $\begin{array}{c}\text { Soil } \\
\text { aggregate }\end{array}$ & $\begin{array}{r}\text { Bulk } \\
\text { soil } \\
\end{array}$ & & $\begin{array}{c}\text { Soil } \\
\text { aggregate }\end{array}$ & $\begin{array}{r}\text { Bulk } \\
\text { soil } \\
\end{array}$ & & $\begin{array}{c}\text { Soil } \\
\text { aggregate }\end{array}$ & $\begin{array}{r}\text { Bulk } \\
\text { soil } \\
\end{array}$ & \\
\hline NV & $43.89 \mathrm{a}$ & $43.02 b$ & 6.83 & $37.64 \mathrm{~b}$ & $36.24 \mathrm{c}$ & 7.06 & $32.63 b$ & $32.94 \mathrm{c}$ & 5.51 \\
\hline $\mathrm{BO}$ & $40.73 a$ & $41.48 b$ & 6.16 & $34.17 \mathrm{c}$ & $33.60 \mathrm{c}$ & 6.85 & $30.20 \mathrm{~b}$ & $36.61 \mathrm{a}$ & 1.63 \\
\hline RY & $44.59 \mathrm{a}^{*}$ & $38.92 \mathrm{c}$ & 6.24 & $36.77 b$ & $36.21 \mathrm{c}$ & 4.97 & $32.39 b$ & $34.74 b$ & 3.33 \\
\hline OR & $45.39 \mathrm{a}$ & $45.48 \mathrm{a}$ & 3.39 & $43.83 \mathrm{a}^{*}$ & $39.90 b$ & 2.43 & $38.54 \mathrm{a}$ & $39.10 \mathrm{a}$ & 4.66 \\
\hline $\mathrm{RY}+\mathrm{OR}$ & $44.70 \mathrm{a}$ & $43.09 \mathrm{~b}$ & 3.09 & $39.00 \mathrm{~b}$ & $45.59 \mathrm{a}$ & 7.95 & $32.29 b$ & $36.42 \mathrm{a}$ & 3.49 \\
\hline $\mathrm{BO}+\mathrm{OR}$ & $42.71 \mathrm{a}$ & $45.70 \mathrm{a}$ & $\mathbf{5 . 5 0}$ & $38.09 \mathrm{~b}$ & $40.82 b$ & 7.89 & $32.77 b$ & $33.68 \mathrm{c}$ & 9.27 \\
\hline CTS & $39.15 a^{*}$ & $34.79 \mathrm{~d}$ & 6.22 & $40.09 \mathrm{~b} *$ & $35.84 \mathrm{c}$ & 6.07 & $37.15 \mathrm{a}$ & $33.75 \mathrm{c}$ & 7.96 \\
\hline CV $(\%)$ & 5.37 & 5.56 & & 5.95 & 6.90 & & 4.89 & 6.70 & \\
\hline Native Forest (CI) & $4.58 * \pm 0.79$ & $0.94 \pm 3.53$ & & $52.84 * \pm 1.99$ & $60.16 \pm 1.51$ & & $51.19 \pm 1.17$ & $47.64 \pm 2.24$ & \\
\hline
\end{tabular}

$\mathrm{NV}=$ natural vegetation; $\mathrm{BO}=$ black oats; $\mathrm{RY}=$ rye; $\mathrm{OR}=$ oilseed radish; $\mathrm{CTS}=$ conventional tillage system; $\mathrm{CV}=$ Coefficient of variation; $\mathrm{CI}=$ Confidence interval. Means followed by the same letter in each column do not differ according to the Skott-Knott test at $5 \%$ probability. *Means of four replications in the rows comparing aggregates and bulk soil showed significant effects by the LSD t test at 5\% probability to compare TOC concentration between aggregates and bulk soil. The results found for the forest area are expressed as 
means \pm confidence interval (Mean \pm CI 95\%).

In the $10-20 \mathrm{~cm}$ soil layer, the treatments with the highest TOC contents in soil aggregates were OR and CTS. The highest TOC in the bulk soil occurred in the treatments BO, OR, and $\mathrm{RY}+\mathrm{OR}$ (Table 2). In the CTS area difference, TOC contents in aggregates were $10 \%$ higher than in bulk soil.

Bulk soil TOC contents in the CTS area were, in general, lower than in the NTVS plots, especially in the upper soil layer. TOC contents differed between aggregates and bulk soil in the CTS area, in all soil layers. On the other hand, NTV TOC contents varied less between aggregates and bulk soil (Table 2). The lowest TOC contents in CTS always occurred in the bulk soil compared with TOC in aggregates. Ferreira et al. (2018) found higher TOC contents in the bulk soil in CTS. That probably was due to the rupture of soil aggregates, which accelerated the decomposition of SOM protected inside aggregates, leading to increases in the SOM decomposition rate and lower TOC contents in the bulk soil.

The plots with cover crops had higher TOC in the upper soil layer than the CTS area, although they were lower than in the reference native forest area. Changes in soil TOC contents and aggregate stability result from residue accumulation and consequent increases in microbial activity in the soil, which carry out biochemical processes that promote soil structure (Rillig \& Mummey, 2006).

The higher TOC contents in the treatments with OR, either single or intercropped with BO or $\mathrm{RY}$, can be attributed to the decomposition of plant residues on the soil, promoting a slow and gradual release of nutrients (Crusciol et al., 2005; Doneda et al., 2012). Studies with cover crops in the same area of the present study showed positive effects of OR on nutrient accumulation and release (Souza et al., 2013; Oliveira et al., 2016) linked to rapid initial plant growth and high dry matter yield (Table 1) (Lima et al., 2007). According to Comin et al. (2018a), winter grasses (RY and BO) in rotation with millet for onion crops in the NTVS increase soil TOC contents in the surface soil layer $(0-5 \mathrm{~cm})$, a behavior that occurred in the present study (Table 2).

BO and RY species have intense tillering and deep, fasciculate root systems, which allow for water and nutrient uptake in deeper soil layers (Souza et al., 2013; Oliveira et al., 2016). Those grasses also have high dry matter production (Table 1), high lignin, and $\mathrm{C}$ to $\mathrm{N}$ and Lignin to $\mathrm{N}$ ratios. Therefore, their residues remain longer on the soil surface, reducing the incidence of natural vegetation and competition with onion plants (Oliveira et al., 2016).

The higher TOC contents in aggregates in the 10-20 cm layer of the CTS area can be due to millet as a cover crop, which contributed to TOC contents similar to those in the NTVS treatments. Millet has a slow decomposition rate due to its high $\mathrm{C} / \mathrm{N}$ ratio at the flowering stage (Kliemann et al., 2006) and its high biomass production, which reached $9.6 \mathrm{Mg}$ ha-1 in the flowering stage, and $14 \mathrm{Mg}$ ha-1 100 days after sowing in the same experimental area (Oliveira et al., 2002; Teixeira et al. 2005).

\subsection{Aggregate Weighted Diameter (WMD), Geometric Diameter (GMD), and Mass Distribution by Diameter Class}




\section{Macrothink}

TOC contents (Table 2) presented significant relation with the stability of soil aggregates (Table 3 and Figure 2) due to the use of NTVS combined with cover crops, such as leguminous and grass species, as also found by Loss et al. (2017) and Ferreira et al. (2018). Over the eight years of the experiment, the treatments using cover crops in both NTVS and CTS added different amounts of plant residues to the soil (Table 1).

The use of BO or RY, either sole or intercropped with OR during the winter and velvet bean during the summer, positively affected the soil aggregation. These species present a pivoting root system that contributes to soil compression as their roots develop. The fasciculate and dense root system of oilseed radish plants contributes to distributing root exudates in the soil (Casali, 2012). However, the use of velvet bean during summer in all treatments produced high dry matter yields, contributing to the addition of nutrients into the soil (Loss et al., 2015).

All treatments under NTVS using winter cover crops, and even that with natural vegetation (NV), had WMD and GMD approximately 10\% higher than those found in the CTS treatment, and approximately $5 \%$ higher than those in the native forest, in the soil surface layer $(0-5 \mathrm{~cm})$ (Table 3). These results confirm those found for water-stable aggregates in the same soil layer, in which treatments using winter cover crops had the highest macroaggregate mass ( $\mathrm{g}$ ). The use of cover crops increased the aggregate mass by $13 \%$, on average, compared with the CTS, the treatment with the lowest macroaggregate mass $(\mathrm{g})$ in the $0-5$ and $5-10 \mathrm{~cm}$ soil layers (Figure 2(a)).
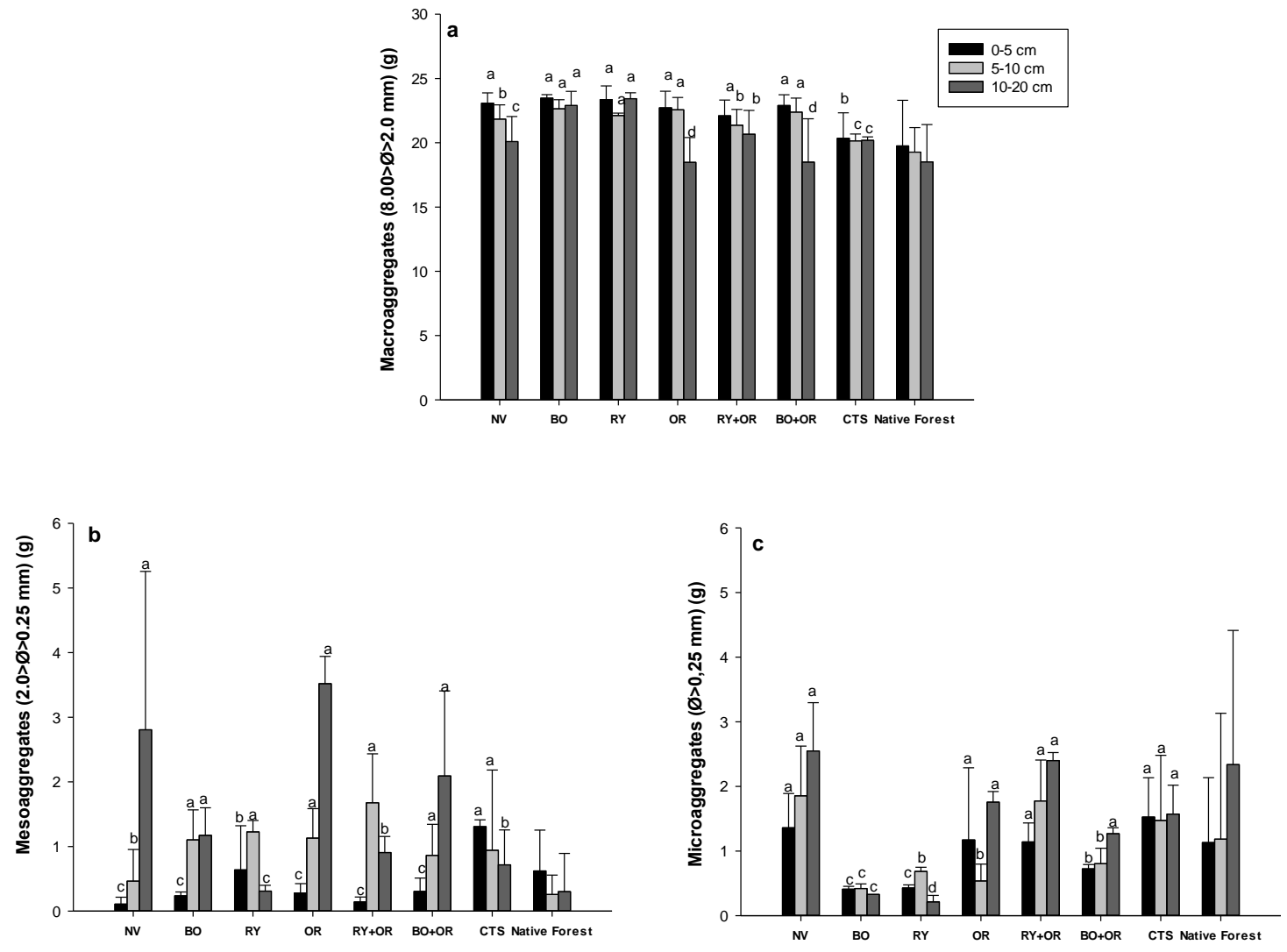

Figure 2. Mass distribution of water-stable macroaggregates $(8.00>\emptyset \geq 2.0 \mathrm{~mm})$ (a), 
mesoaggregates $(2.0>\varnothing \geq 0.25 \mathrm{~mm})(\mathrm{b})$, and microaggregates $(\varnothing<0.25 \mathrm{~mm})(\mathrm{c})$ in the $0-5,5-0$, and 10-20 cm layers of soil with onion crop systems. $\mathrm{NV}=$ natural vegetation; $\mathrm{BO}=$ black oats; $\mathrm{RY}=$ rye; $\mathrm{OR}=$ oilseed radish CTS = conventional tillage system; $\mathrm{CV}=$ Coefficient of variation; $\mathrm{CI}=$ Confidence interval. Means followed by the same letter in the columns do not differ according to the Skott-Knott test at 5\% probability. The results for the forest area are expressed as means \pm confidence interval (Mean \pm CI 95\%).

Soil TOC contents also affect the size and mass distribution of soil aggregates, significantly affected by changes in the soil management system (Li et al., 2018). Different cover crop species, such as rye, oats, and millet, can positively affect those changes. These species produce large amounts of dry matter, have high nutrient cycling efficiency, and present dense, fasciculate root systems that can explore deeper soil layers (Calegari, 2008; Lima Filho et al., 2014). This dynamic was found in the treatments under NTVS, which had higher TOC contents (Table 2), WMD, GMD, and macroaggregate mass in the soil surface layer (Table 3, Figure 2(a)), compared with the CTS treatment, which had no winter cover crops.

Table 3. Aggregate weighted mean diameter (WMD) and geometric mean diameter (GMD) from 0-5, 5-10, and 10-20 cm layers of soils under different management systems for onion crops

WMD

\section{Treatments}

Treatments

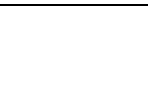

\section{GMD}

\begin{tabular}{lcccccc} 
& $0-5$ & $5-10$ & $10-20$ & $0-5$ & $5-10$ & $10-20$ \\
\hline NV & $4.80 \mathrm{a}$ & $4.58 \mathrm{a}$ & $4.27 \mathrm{~b}$ & $4.23 \mathrm{a}$ & $3.72 \mathrm{~b}$ & $3.13 \mathrm{c}$ \\
BO & $4.85 \mathrm{a}$ & $4.80 \mathrm{a}$ & $4.79 \mathrm{a}$ & $4.59 \mathrm{a}$ & $4.45 \mathrm{a}$ & $4.44 \mathrm{a}$ \\
$\mathbf{R Y}$ & $4.84 \mathrm{a}$ & $4.74 \mathrm{a}$ & $4.89 \mathrm{a}$ & $4.39 \mathrm{a}$ & $4.20 \mathrm{a}$ & $4.68 \mathrm{a}$ \\
OR & $4.60 \mathrm{a}$ & $4.66 \mathrm{a}$ & $4.17 \mathrm{~b}$ & $4.20 \mathrm{a}$ & $4.22 \mathrm{a}$ & $2.85 \mathrm{c}$ \\
RY+OR & $4.76 \mathrm{a}$ & $4.41 \mathrm{~b}$ & $4.33 \mathrm{~b}$ & $3.98 \mathrm{a}$ & $3.32 \mathrm{~b}$ & $2.88 \mathrm{c}$ \\
BO+OR & $4.74 \mathrm{a}$ & $4.65 \mathrm{a}$ & $3.98 \mathrm{~b}$ & $4.15 \mathrm{a}$ & $3.98 \mathrm{a}$ & $2.95 \mathrm{c}$ \\
CTS & $4.46 \mathrm{~b}$ & $4.43 \mathrm{~b}$ & $4.41 \mathrm{~b}$ & $3.45 \mathrm{~b}$ & $3.19 \mathrm{~b}$ & $3.52 \mathrm{~b}$ \\
\hline CV (\%) & $\mathbf{2 . 7 4}$ & $\mathbf{3 . 2 0}$ & $\mathbf{4 . 3 3}$ & $\mathbf{8 . 4 0}$ & $\mathbf{9 . 2 1}$ & $\mathbf{6 . 7 0}$ \\
\hline
\end{tabular}

Native Forest (CI) $\quad 4.62 \pm 0.06 \quad 4.63 \pm 0.06 \quad 4.39 \pm 0.15 \quad 3.80 \pm 0.21 \quad 3.80 \pm 0.17 \quad 3.05 \pm 0.46$ 
$\mathrm{NV}=$ natural vegetation; $\mathrm{BO}=$ black oat $\mathrm{RY}=$ rye; $\mathrm{OR}=$ oilseed radish CTS = conventional tillage system; $\mathrm{CV}=$ Coefficient of variation; $\mathrm{CI}=$ Confidence interval. Means of followed by the same letter in each column do not differ according to the Skott-Knott test at 5\% probability. The results found for the forest area are expressed as means \pm confidence interval (Mean \pm CI 95\%).

The decomposition of the cover crops, either sole or intercropped, in areas for onion crops in NTVS may also affect the release of exudates, known as polysaccharides, cementing substances. These substances are responsible for stabilizing soil particles, which are also interwoven with fungal hyphae and roots of cover crops and contribute to increases in the activity of microorganisms in the soil, especially AMF (Rillig \& Mummey, 2006). The soil biota activity affects the soil structure and, consequently, increases the WMD and GMD (Grimaldi et al., 2003; Tisdall \& Oades, 1982).

The highest WMD and GMD in the 10-20 cm soil layer occurred in the BO and RY treatments, with means $25 \%$ and $35 \%$ higher than those found in the CTS treatment and the native forest, respectively (Table 3). Grasses such as black oats have shown relative higher root densities, which can reach $0.76 \mathrm{~m}$ and result in a better root system distribution in the soil, favoring the joint of soil mineral particles (clay, silt, and sand) and the formation of stable aggregates, as found for rye, whose root system can reach $1.22 \mathrm{~m}$ (Weaver, 1926).

The soil management practices used in CTS resulted in the highest microaggregate mass $(\varnothing<0.25 \mathrm{~mm}$ ) (Figure 2(c)) in the $0-5 \mathrm{~cm}$ soil layer, which was approximately $75 \%$ higher than those in the treatments under NTVS with the use of winter cover crops. The NV treatment had a higher microaggregate mass $(\varnothing<0.25 \mathrm{~mm})$ in all soil layers. That can be attributed to the plant species' root systems in this treatment, mainly in the soil surface layer, differing from those of the black oats and rye. The macro-, meso-, and microaggregate masses of the treatments with cover crops were similar, denoting the importance of cover crops to improve aggregation conditions in soils with onion crops under NTVS, confirming the results of Loss et al. (2017).

The predominance of small-diameter aggregates in the CTS treatment (Figure 2) can be attributed to soil tillage. Comparing the soil physical attributes in the same area of the present study, Loss et al. (2017) found increases in soil aggregation indexes, higher in treatments under NTVS relative to CTS after five years of NTVS implementation. Moreover, soil tillage restricted to the planting rows in NTVS preserves the fungal hyphae and favors the formation and distribution of soil macroaggregates, increasing nutrient availability and soil water retention (Wright et al., 2003; Wright \& Upadhyaya, 1998).

Treatments with intercrops of cover species also create a favorable environment for the formation and maintenance of soil aggregates because of the different root systems (Loss et al., 2017; Comin et al., 2018a; Ferreira et al., 2018), affecting WMD and GMD (Table 3), and raising TOC contents (Table 2), besides the positive effects of their high dry matter yield (Table 1). However, better soil aggregation results in the $10-20 \mathrm{~cm}$ layer were found in the treatments with BO and RY grown in single crops, compared with those with these grasses intercropped with OR. This result can be due to those plants' residues on the soil surface, which protected the soil against raindrop impacts and, consequently, decreased soil, water, and 
nutrient loss by runoff (Busari et al., 2015). Oliveira et al. (2016) found that these species affect nutrient cycling in the soil because their decomposition promotes a slow release of nutrients.

\subsection{Total Glomalin (TG) and Easily Extractable Glomalin (EEG) Contents}

In the soil surface layer $(0-10 \mathrm{~cm})$, the use of cover crops, singly (BO, RY, and OR) or intercropped (BO+OR and $\mathrm{RY}+\mathrm{OR})$, and the natural vegetation $(\mathrm{NV})$ affected the glomalin fractions positively in soils with onion crops under NTVS. Glomalin values were always higher in NTVS than in CTS and were similar to those found in the native forest area (Table 4). Soil glomalin fractions depend on several factors, including the AMF occurrence, plant community composition, soil properties, and soil management. Our results confirm the positive correlation of these fractions with the highest soil TOC contents (Table 2, 0-5 cm), aggregation indexes (Table 3, 0-5 cm), and macroaggregate mass (Figure 2 (a)).

Total glomalin (TG) represents the amount of total protein on the surface and inside aggregates (Wright \& Upadhyaya, 1998). TG varied in the treatments with cover crops from 209.43 to $245.39 \mu \mathrm{g} g-1$ and was $84.08 \%$ higher than that found in the treatment CTS (125.88 $\mu \mathrm{g} \mathrm{g}-1)$. The low TG and EEG found in the treatment NV can be related to the low amounts of biomass from the cover crops in this treatment (Table 1), resulting in the lowest GMD and macroaggregate mass.

The lowest TG and EEG in the CTS treatment can be related to environmental changes promoted by this cropping system (Table 4). Soil management systems that use intensive mechanization, agrochemicals, and genetically modified plant varieties disfavor the soil AMF population (Moreira \& Siqueira, 2006). The use of these practices in the CTS promotes soil disaggregation and rupture of mycelia, exposing AMF propagules to oxidation, making them unviable and decreasing the mycorrhizal colonization (Schneider et al., 2011).

EEG represents the most recently produced protein in the soil, more susceptible to decomposition because it is predominantly on the aggregate surface (Wright \& Upahyaya, 1998). The treatments with cover crops also presented higher EEG, which ranged from 65.91 $\mu \mathrm{g}$ g-1 to $58.60 \mu \mathrm{g}$ g-1, and were $60 \%$ higher than EEG in the CTS treatment (EEG of $34.03 \mu \mathrm{g}$ g-1).

The correlation between TG and EEG with soil physical attributes (WMD and GMD) was significant $(r>0.60)$. That indicates an effect of cover crops on soil surface layer TG $(0-5$ and $5-10 \mathrm{~cm}$ ) and macroaggregate mass distribution ( $\mathrm{r}=0.63$ and $\mathrm{r}=0.63)$ in the $0-5 \mathrm{~cm}$ layer, and on EEG in the 5-10 cm layer $(r=0.61$ and $r=0.62)$. TG and EEG's correlation with the mesoaggregate mass in the $0-5 \mathrm{~cm}$ layer was also significant ( $\mathrm{r}=0.63$ and $\mathrm{r}=0.66)$. Our results confirm those of Wright \& Upadhyaya (1998), who found a high correlation between glomalin contents and soil aggregate stability, confirming this protein's contribution to soil physical quality. 
Information about factors controlling TG and EEG fractions is vital for defining management strategies to improve soil structure and, consequently, increase crop yield and decrease environmental impacts by agricultural production systems.

Table 4. Total glomalin (TG) and easily extractable glomalin (EEG) concentration in the 0-10 cm layer of soils under different onion crop systems

\begin{tabular}{|c|c|c|}
\hline Treatments & TG & EEG \\
\hline NV & $209.43 a$ & $54.24 \mathrm{a}$ \\
\hline BO & $245.39 a$ & $65.91 \mathrm{a}$ \\
\hline RY & $231.28 \mathrm{a}$ & $58.91 \mathrm{a}$ \\
\hline OR & $230.93 a$ & $58.99 \mathrm{a}$ \\
\hline $\mathrm{BO}+\mathrm{OR}$ & $241.90 \mathrm{a}$ & $61.32 \mathrm{a}$ \\
\hline $\mathbf{R Y + O R}$ & $231.46 a$ & $58.60 \mathrm{a}$ \\
\hline CTS & $125.88 b$ & $34.03 b$ \\
\hline $\mathrm{CV}(\%)$ & 12.64 & 13.12 \\
\hline Native Forest (CI) & $234.21 \pm 3.15$ & $64.12 \pm 2.10$ \\
\hline
\end{tabular}

$\mathrm{NV}=$ natural vegetation; $\mathrm{BO}=$ black oats; $\mathrm{RY}=$ rye; $\mathrm{OR}=$ oilseed radish; $\mathrm{CTS}=$ conventional tillage system; $\mathrm{CV}=$ Coefficient of variation; $\mathrm{CI}=$ Confidence interval. Means followed by the same letter in each column do not differ according to the Skott-Knott test at $5 \%$ probability. The results found for the forest area are expressed as means \pm confidence interval (Mean \pm CI 95\%).

\subsection{Principal Component Analysis (PCA)}

In the multivariate principal component analysis, $51.77 \%$ of the variance was explained by the principal components PC1 and PC2 (Figure 3). The first component (PC1) explained $31.71 \%$ of the variance in soil attributes. This component ranked the soil physical attributes with the highest correlation with the principal components: WMD, GMD, macroaggregate mass, 
microaggregate mass (in all three evaluated layers), and TOC contents in soil aggregates in the $10-20 \mathrm{~cm}$ layer (TOC20AG).

The second component (PC2) explained $20.07 \%$ of the accumulated variance. PC2 highlighted the soil TOC contents in the aggregate and bulk soil samples from the $0-5$ and $5-10 \mathrm{~cm}$ soil layers (TOC5, TOC10, and TOC5AG, TOC10AG) (Figure 3). PC2 also highlighted WMD and GMD in the 10-20 cm layer (WMD20, GMD20), macroaggregate mass in the 10-20 cm layer (Macro20), mesoaggregates in the 5-10 and 10-20 cm layers (Meso10 and Meso20), microaggregates in the 10-20 layer (Micro20), and the microbiological attributes total glomalin (TG) and easily extractable glomalin (EEG) contents.

The ordination diagram produced by the PCA for the data collected from the different treatments (Figure 3) showed three different groups and the formation of two groups related to treatments in NTVS (NV, BO, RY, OR, and their intercrops) opposite to the CTS. The use of cover crops showed positive effects on GMD20, WMD20, Micro5, Micro10, Micro20, and Meso20, and TOC contents in aggregates and bulk soil, in all evaluated layers.

Meso5 was the nearest variable to CTS, with a strong correlation (0.29 in the PC2, Figure 3) in the distancing of CTS from the other treatments. That indicates that the CTS treatment favored the increase of mesoaggregates (Figure 2B); the highest mesoaggregate masses in the soil surface layer occurred in this treatment. GMD5, GMD10, WMD5, Macro5, Macro10, EEG, TG, TOC5, and TOC10 are opposite to the treatment CTS in the diagram, indicating that the CTS affected these variables negatively. This result is confirmed in Table 2, where the treatment CTS showed the lowest TOC contents; in Table 3, CTS was linked to the lowest WMD and GMD. That also is shown in Figure 2a, where CTS had low macroaggregate mass, and in Table 4, where it showed lower TG and EEG than the other treatments.

The $\mathrm{BO}$ and $\mathrm{BO}+\mathrm{OR}$ treatments separated from the others because of WMD, GMD, Macro (10-20 cm layer), Meso10, WMD10, and onion yield. This group was opposed to the other treatments (NV, RY, OR, and RY+OR), separated by TOC contents, mesoaggregates, and microaggregates (Figure 5). Those results point to the importance of cover crops for soil physical, chemical, and biological attributes, which are important indicators of soil aggregate formation, stability, and soil chemical attributes.

Our results confirm those by Loss et al. (2017), who found higher TOC contents in soil surface layers, showing that onion crops in NTVS increase SOM contents and, consequently, soil physical attributes. TOC remains protected inside macroaggregates by joining microaggregates. In contrast, CTS management practices expose organic carbon to degradation processes due to soil disaggregation into smaller structures (microaggregates) and even by dividing microaggregates into dispersed particles. Those processes expose the organic carbon protected from soil microorganisms' degradation (Tivet et al., 2013). 


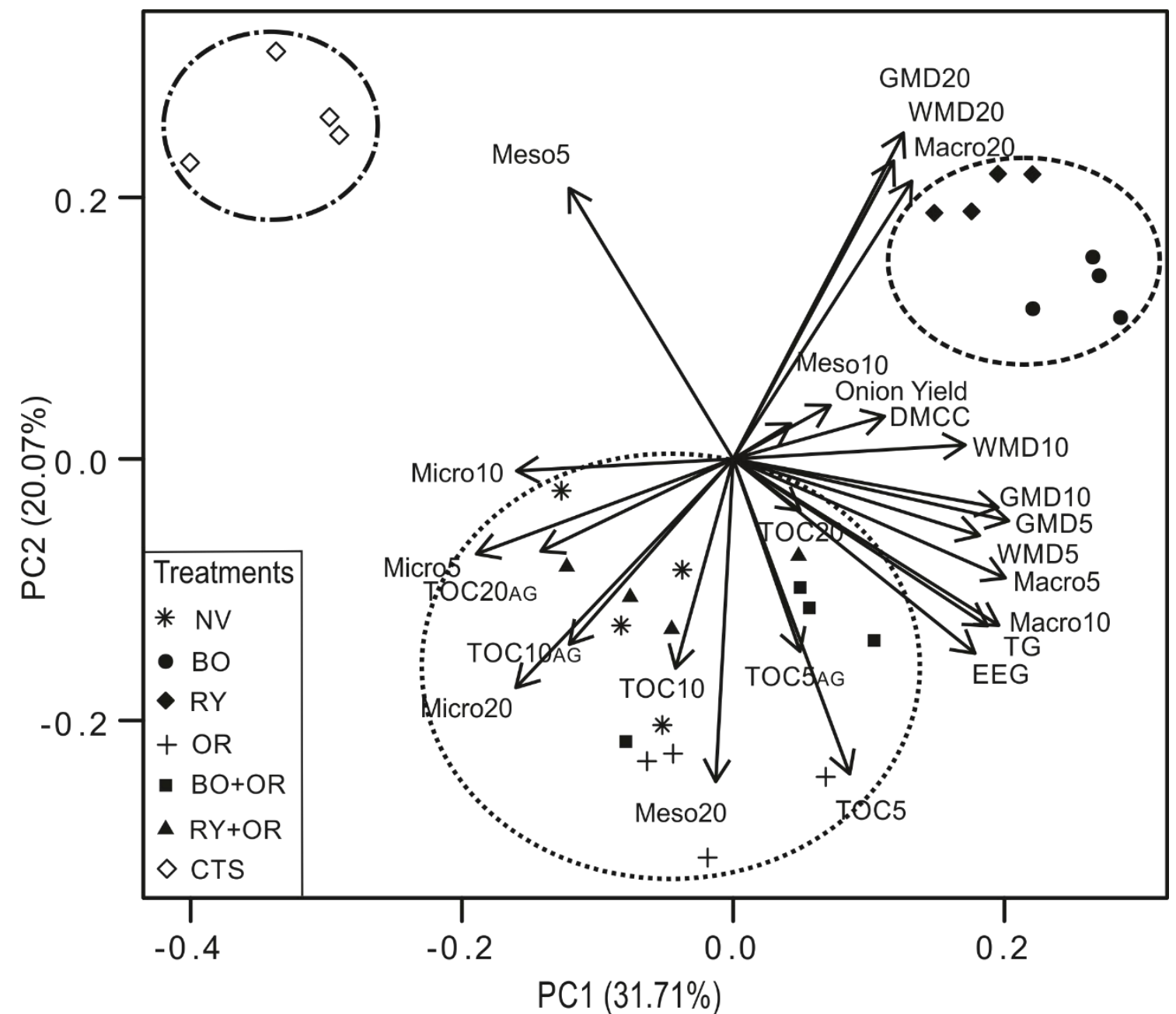

Figure 3. Ordination diagram produced by principal component analysis for data collected from different treatments with onion crops under NTVS and conventional tillage system (CTS) for eight years. $\mathrm{NV}=$ natural vegetation; $\mathrm{BO}=$ black oats; $\mathrm{RY}=$ rye; $\mathrm{OR}=$ oilseed radish; CTS = conventional tillage system; OY= Onion yield; DMCC: Dry matter of soil cover crops; TOC5 $=$ total organic carbon in the $0-5 \mathrm{~cm}$ soil layer; TOC10 = total organic carbon in the $5-10 \mathrm{~cm}$ soil layer; TOC20 = total organic carbon in the $10-20 \mathrm{~cm}$ soil layer; TOC $5_{\mathrm{AG}}=$ total organic carbon in aggregates in the $0-5 \mathrm{~cm}$ soil layer $; \mathrm{TOC} 10_{\mathrm{AG}}=$ total organic carbon in aggregates in the $5-10 \mathrm{~cm}$ soil layer $;$ TOC $20_{\mathrm{AG}}=$ total organic carbon in aggregates in the 10-20 cm soil layer; WMD5 = weighted mean diameter in the $0-5 \mathrm{~cm}$ soil layer; $\mathrm{WMD} 10=$ weighted mean diameter in the $5-10 \mathrm{~cm}$ soil layer; $\mathrm{WMD} 20=$ weighted mean diameter in the 10-20 cm soil layer; GMD5 = weighted mean diameter in the $0-5 \mathrm{~cm}$ soil layer; GMD10 = weighted mean diameter in the 5-10 cm soil layer; GMD20 $=$ weighted mean diameter in the $10-20 \mathrm{~cm}$ soil layer; Macro5 = soil macroaggregates in the $0-5 \mathrm{~cm}$ soil layer; Macro10 = soil macroaggregates in the $5-10 \mathrm{~cm}$ soil layer; Macro20 = soil macroaggregates in the $10-20 \mathrm{~cm}$ soil layer; Meso5 = soil mesoaggregates in the $0-5 \mathrm{~cm}$ soil layer; Meso10 = soil mesoaggregates in the $5-10 \mathrm{~cm}$ soil layer; Meso20 = soil mesoaggregates in the 10-20 cm soil layer; Micro5 = soil microaggregates in the $0-5 \mathrm{~cm}$ soil layer; Micro10 = soil microaggregates in the $5-10 \mathrm{~cm}$ soil layer; Micro20 = soil microaggregates in the $10-20 \mathrm{~cm}$ soil layer; $\mathrm{TG}=$ total glomalin concentration; $\mathrm{EEG}=$ easily 
extractable glomalin concentration.

Loss et al. (2015) evaluated onion crops in NTVS and CTS using PCA and found that NTVS with different cover crops favored soil chemical, physical, and biological processes that affect the formation and stability of soil aggregates, reflected in macroaggregate mass, WMD, and GMD. Residues produced by the cover crops evaluated in the NTVS over the eight years of the experiment showed a positive effect on soil attributes related to aggregation, TOC contents, and onion yield in this system, which was $8 \%$ higher when compared to CTS (Table 1).

\section{Conclusions}

The use of different cover crops over eight years for onion crops under the vegetable crop no-tillage system (NTVS) affected soil physical attributes, especially aggregation.

Black oats and rye used as cover crops, either sole or intercropped with oilseed radish, increased aggregates' stability in the soil surface layer, while black oats and rye enhanced macroaggregate formation in deeper soil layers.

Oilseed radish, sole or intercropped with black oats, increased soil total organic carbon, and black oats increased the total glomalin by $84 \%$ and easily extractable glomalin contents by $60 \%$ in the soil surface layers, factors that are linked to soil aggregation.

A principal component analysis (PCA). PCA showed the adverse effects of tillage on soil physical attributes and demonstrated that no-tillage areas with black oats, sole or intercropped with oilseed radish, differed from the other cover crop treatments.

\section{Acknowledgments}

This work was funded by Coordenação de Aperfeiçoamento de Pessoal de Nível Superior (CAPES) and the National Council for Scientific and Technological Development $-\mathrm{CNPq}^{\circ}{ }^{\circ}$ 487492/2013-7. The authors express their thanks to Experimental Station (EPAGRI) of Ituporanga, Santa Catarina, Brazil, for the experimental area and technical help.

\section{References}

Altieri, M. A., Lana, M. A., Bittencourt, H. V., Kieling, A. S., Comin, J. J., \& Lovato, P. E. (2011). Enhancing Crop Productivity via Weed Suppression in Organic No-Till Cropping Systems in Santa Catarina, Brazil. J. Sustain. Agric., 35, 1-15. https://doi.org/10.1080/10440046.2011.588998

Brennan, E.R, \& Richard, F.S. (2005). Winter Cover Crop Growth and Weed Suppression on the Central Coast of California. Weed Technology, 14(4), 1017-1028. https://doi.org/10.1614/WT-04-246R1.11

Busari, M. A., Kukal, S. S., Kaur, A., Bhatt, R., \& Dulazi, A. A. (2015). Conservation tillage impacts on soil, crop and he environment. International Soil and Water Conservation Research, 3, 119-129. https://doi.org/10.1016/jiswcr.2015.05.002

Calegari, A., Mondardo, A., Bulisani, E. A., Costa, M. B. B., Da Miyasaka, S., \& Amado, T. J. C. (1993). Aspectos gerais da adubação verde. In: Costa, M. B. B. dá 
(Coord.). Adubação verde no sul do Brasil. Rio de Janeiro: Assessoria e Serviços a Projetos em Agricultura Alternativa, 2, 1-56.

Casali C. A. (2012) Sistemas de culturas sob diferentes manejos em longa duração alteram as formas de fósforo do solo [tese]. Santa Maria: Universidade Federal de Santa Maria. 149p.

Comin, J. J., Ferreira, L. B., Santos, L. H., Koucher, L. P., Machado, L. N., Santos, E., ... Loss, A. (2018 a). Carbon and nitrogen contents and aggregation index of soil cultivated with onion for seven years using crop successions and rotations. Soil \& Tillage Research, 184, 195-202. https://doi.org/10.1016/j.still.2018.08.002

Comin, J. J., Vilanova, C. C., Kurtz, C., Júnior, V. M., Ventura, B., Reis, M. S., ... Souza, M. (2018b). Avaliação fitossociológica de plantas invasoras em cultivo de cebola sob sistema plantio direto sem uso de agrotóxicos. Revista de La Facultad de Agronomía (La Plata), $117(2), 197-206$.

Costa Junior, C., Piccolo, M. C., Neto, M. S., Camargo, P. B., Cerri, C. C., \& Bernoux, M. (2012). Carbono em agregados do solo sob vegetação nativa, pastagem e sistemas agrícolas no bioma cerrado. Revista Brasileira de Ciência do Solo, 36, 1311-1321. https://doi.org/10.1590/S0100-06832012000400025

Crusciol, C. A. C., Cottica, R. L., Lima, E. D., Andreotti, M., Moro, E., \& Marcon, E. (2005). Persistência de palhada e liberação de nutrientes do nabo forrageiro no plantio direto. Pesquisa Agropecuária Brasileira, 40, 161-168.

https://doi.org/10.1590/S0100-204X2005000200009

Doneda, A., Aita, C., Giacomini, S.J., Miola, E.C.C., Giacomini, D. A., Schirmann, J., \& Gonzatto, R. (2012). Fitomassa e decomposição de resíduos de plantas de cobertura puras e consorciadas. Revista Brasileira de Ciência do Solo, 36, 1714-1723. https://doi.org/10.1590/S0100-06832012000600005

EMPRESA BRASILEIRA DE PESQUISA AGROPECUÁRIA - EMBRAPA (1997). Manual de métodos de análise de solo / Centro Nacional de Pesquisa de Solos. - 2. ed. rev. atual. Rio de Janeiro, 212p.

EMPRESA BRASILEIRA DE PESQUISA AGROPECUÁRIA - EMBRAPA (2013). Sistema Brasileiro de Classificação de Solos. 2aed. Brasília: Embrapa Produção de informação; Rio de Janeiro: Embrapa Solos, 312p.

EPAGRI/CEPA. Boletim Agropecuário. (Junho/2019) (Epagri. Documentos, 295).

Florianópolis, 48p.

Ferreira, L. B., Loss, A., Giumbelli, L. D., Ventura, B., Souza, M., Mafra, A. L., ... Brunetto, G. (2018). Organic carbon and nitrogen contents and their fractions in soils with onion crops in different management systems. Soil e Tillage Research, 1-10. https://doi.org/10.1071/SR18167

Grimaldi, M., Schroth, G., Teixeira, W., \& Huwe, B. Soil Structure. In: SCHROTH, G.; SINCLAIR, F. L. (Ed.) (2003). Trees, crops and soil fertility: concepts and research methods. Trowbridge: CABI Publishing, 191-208. 
Hammerschimidt, I., Madeira, N. R., \& Oliveira, V. R. (2013). Cultivo de Cebola em Sistema de Plantio Direto. 1. ed. Curitiba: Instituto Emater, 1, 24p.

Júnior, V. M., Comin, J. J., Koucher, L. P., Brunetto, G., Lovato, P. E., Souza, M., ... Giacomini, S. J. (2019). Nitrous Oxide Emissions in No-Tillage Onion (Allium cepa L.) Crops Are Increased by Oilseed Radish Cover Crop and Poultry Manure Application. Revista Brasileira De Ciência Do Solo (ONLINE), 43, 1-13.

https://doi.org/10.1590/18069657rbcs20180116

Kliemann, J. H., Braz, A. J. P. B., \& Silveira, P. M. (2006). Taxas de decomposição de resíduos de espécies de cobertura em Latossolo Vermelho Distroférrico. Pesquisa Agropecuária Tropical, 36, 21-28.

Li, F., Xue, C., Qiu, P., Liu, Y., Shi, J., Shen, B., ... Shen, Q. (2018). Soil aggregate size mediates the responses of microbial communities to crop rotation. European Journal of Soil Biology, 88, 48-56. https://doi.org/10.1016/j.ejsobi.2018.06.004

Lima Filho O. F., Ambrosano E. J., Rossi, F., \& Carlos, J. A. D. (2014). Adubação verde e plantas de cobertura no Brasil: fundamentos e prática. v.1. Brasília, DF: Embrapa, 481 p.

Lima, J. D., Aldrighi, M., Sakai, R. K., Soliman, E. P., \& Moraes, W. S. (2007). Comportamento do nabo-forrageiro (Raphanus sativus L.) e da nabiça (Raphanus raphanistrum L.) como adubo verde. Pesquisa Agropecuária Tropical, 37(1), 60-63. https://doi.org/10,5216/pat.v.37i1.1871

Loss, A., Basso, A., Oliveira, B. S., Koucher, L. P., Oliveira, R. A., Kurtz, C., ... Comin, J. J. (2015). Carbono orgânico total e agregação do solo em sistema de plantio direto agroecológico e convencional de cebola. Revista Brasileira de Ciência do Solo, 39, 1212-1224. https://doi.org/10.1590/01000683RBCS20140718

Loss, A., Junior, E. D. S., Schmitz, D., Veiga, M. D., Kurtz, C., \& Comin, J. J. (2017). Soil physical attributes of onion cultivation under notillage and conventional tillage systems. Revista Colombiana de Ciencias Hortícolas, 11(1), 105-113.

https://doi.org/10.17584/rcch.2017v11i1.6144

Mafra, A. L., Marquesi, D. R., Fayad, J. A., Comin, J. J., \& Arl, V. (2019). Sistema de plantio direto de hortaliças - método de transição para um novo modo de produção. Editora Expressão Popular, 432p.

Monegat, C. Plantas de cobertura do solo: Características e manejo em pequenas propriedades, (1991). Chapecó: Edição do Autor, 337p.

Moreira, F.M.S., Siqueira, J.O. Microbiologia \& Bioquímica do Solo, (2006). 2. ed. atual. e ampl. Lavras: Editora UFLA, 729p.

Nichols, K. A., \& Wright, S. F. (2005). Comparison of glomalin and humic acid in eight native US soil, Soil Science, 170(12), 985-997. https://doi.org/0038-W75X/05/17012-985-997

Oliveira, R. A., Brunetto, G., Loss, A., Gatiboni, L. C., Kurtz, C.; Muller, V. M., ... Comin, J. J. (2016). Decomposição e liberação de nutrientes de plantas de cobertura e seus efeitos em atributos químicos do solo e produtividade da cebola. Revista Brasileira Ciência do Solo, 40, 
$1-17$.

Oliveira, T.K., Carvalho, G.J., \& Moraes, R.N.S. (2002). Plantas de cobertura e seus efeitos sobre o feijoeiro em plantio direto. Pesquisa Agropecuaria Brasileira, 37, 1079-1087. https://doi.org/10.1590/S0100-204X2002000800005

Panachucki, E., Bertol, I., Alves Sobrinho, T., Oliveira, P. T. S. DE, \& Rodrigues, D. B. B. (2011). Perdas de solo e de água e infiltração de água em Latossolo vermelho sob sistemas de manejo. Revista Brasileira de Ciência do Solo, 35(5), 1777-1786. https://doi.org/10.1590/S0100-06832011000500032

Rillig, M. C., \& Mummey, D. L. (2006). Mycorrhizas and soil structure. New Phytol, 171, 41-53. https://doi.org/10.1111/j.1469-8137.2006. 01750.x

Rillig, M. C., Ramsey, P. W., Morris, S., \& Paul, E. A. (2003). Glomalin, an arbuscular-mycorrihizal fungal soil protein, responds to land-use chance. Plant and Soil, 253, 293-299. https://doi.org/10.1023/A:1024807820579

Roumet, C., Urcelay, C., \& Días, S. (2006). Suites of root traits differ between annual and perennial species growing in the field. New Phytologist, Cambridge, 170(2), 357-368. https://doi.org/10.1111/j.1469-8137.2006.01667.x

Santos, L. H., Loss, A., Lorenzi, C. R., Souza, M., Gonzatto, R., Kurtz, C., ... Comin, J. J. (2018). Nitrógeno total y sustancias húmicas en agregados del suelo cultivado con cebolla bajo siembra directa y preparación convencional. Revista Colombiana de Ciências Hortícolas, 12, 166-174. https://doi.org/10.17584/rcch.2018v12i1.7339

Schneider, J., Klauberg Filho, O., Fontoura, S. M., \& Alves, M. V. (2011). Influência de diferentes sistemas de manejo e calagem em experimento de longa duração sobre fungos micorrízicos arbusculares. Revista Ciência e Agrotecnologia, Lavras, 35(4), 701-709. https://doi.org/10.1590/S1413-70542011000400008

Silva, A. L., Mafra, A. L., Klauberg Filho, O., Kurtz, C., \& Fayad, J. A. (2014). Carbono e nitrogênio microbiano em sistemas de cultivo de cebola em um Cambissolo Húmico. Revista de Ciências Agroveterinárias, 13(2), 142-150.

Souza, M., Comin, J.J., Leguiizamón, E. S, Kurtz C., Brunetto, G., Muller, J. R. V., Ventura, B., \& Camargo, A. P. (2013). Matéria seca de plantas de cobertura, produção de cebola e atributos químicos do solo em sistema plantio direto agroecológico. Revista Ciência Rural, 43, 21-27. https://doi.org/10.1590/S0103-84782012005000150

Souza, M., Muller J. R., V., Kurtz, C., Brunetto, G., Couto, R. R., \& Comin, J. J. (2018). Weed Emergence in a Soil with Cover Crops in an Agroecological No-Tillage System. Revista Planta Daninha, 36, 1-9. https://doi.org/10.1590/s0100-8358201836010065

Teixeira, C. M., Carvalho, G. J. C., Furtini Neto, A. E., Andrade, M. J. B., \& Marques, E. L. S. (2005). Produção de biomassa e teor de macro nutrientes do milheto, feijão-de-porco e guandu-anão em cultivo solteiro e consorciado. Ciência Agro tecnológica, 29, 93-99. https://doi.org/0.1590/S1413-70542005000100011

Tisdall, J. M., \& Oades, J. M. (1982). Organic matter and waterstable aggregates in soil. 
Journal Soil Science, 33, 141-163. https://doi.org/10.1111/j.1365-2389.1982.tb01755.x

Tivet, F., Sá, J. C. M; Lal, R. B. C., Borszowskei, P. R., Santos, J. B., Farias, A., ... Seguy, L. (2013). Aggregate $\mathrm{C}$ depletion by plowing and its restoration by diverse biomass-C inputs under no-till in sub-tropical and tropical regions of Brazil. Soil Till Res., 18, 126-203. https://doi.org/10.1016/j.still.2012.09.004

Upton, R. N., Bach, E. M., \& Hofmockel, K. S. (2019). Spatio-temporal microbial community dynamics within soil aggregates. Soil Biology and Biochemistry, 132, 58-68. https://doi.org/10.1016/j.soilbio.2019.01.016

Vilanova, C. C., Comin, J. J.; Kurtz, C., Muller Junior, V., Uriarte, J. F., Ventura, B. S., ... Brunetto, G. (2014). Interferência de plantas de cobertura sobre a incidência de plantas invasoras e a produção de cebola sob sistema de plantio direto. Scientia Agrária, 15(1), 9-14. https://doi.org/10.5380/rsa.v15il.41092

Weaver, J. E. (1926). Root Development of Field Crops. (1st ed.), McGraw-Hill, New York. p. 167.

Wright, G. C., Mcloskey, W. B., Closey, W. B., \& Taylor, K. C. (2003). Managing orchard floor vegetation in flood-irrigated citrus groves. Hort Technology, 13, 668-667. https://doi.org/10.21273/HORTTECH.13.4.0668

Wright, S. F. et al., (2007). Glomalin in aggregate size classes from three different farming systems. Soil and Tillage Research, Amsterdan, 94, 546-549. https://doi.org/10.1016/j.still.2006.08.003

Wright, S. F., \& Upadhyaya, A. (1998). A survey of soils for aggregate stability and glomalin, a glycoprotein produced by hyphae of arbuscular mycorrhizal fungi. Plant Soil, 198, 97-107. https://doi.org/10.1023/A:1004347701584

Wright, S. F., Franke-Snyder, M., Morton, J. B., \& Upadhyaya, A. (1996). Time-course study and partial characterization of a protein on hyphae of arbuscular mycorrhizal fungi during active colonization of roots. Plant Soil, 181, 193-203. https://doi.org/10.1007/BF00012053

Yeomans, J. C., \& Bremner, J. M. (1988). A rapid and precise method for routine determination of organic carbon in soil. Communications in Soil Science and Plant Analysis, 19, 1467-1476. https://doi.org/10.1080/00103628809368027

Yoder, R. E. (1936). A direct method of aggregate analysis of soil and a study of the physical nature of erosion losses. Journal of the American Society Agronomy, 28(337), 51.

\section{Copyright Disclaimer}

Copyright for this article is retained by the author(s), with first publication rights granted to the journal.

This is an open-access article distributed under the terms and conditions of the Creative Commons Attribution license (http://creativecommons.org/licenses/by/4.0/). 